\title{
Historical Perspectives on Range Burning in the Inland Pacific Northwest
}

\author{
DEAN A. SHINN
}

\begin{abstract}
Ecological and historical data are combined in assessing the influence of cultural broadcast burning in the inland Pacific Northwest from the distant past into recent history. Twenty-four references to broadcast burning by native peoples were found in the journals of early explorers and settlers. Broadcast burning was apparently an ancient native tradition, derived from the earliest hunting cultures to enter the region. With the influx of European culture, misapprehensions about fire among whites disrupted the original influence of native cultural burning. Early irresponsible burning became associated with the deterioration of natural resources, and efforts to prevent or suppress all fires were incorporated in developing conservation policies. The reduction of burning, combined with markedly intensified grazing by European livestock, distorted the basic character of existing ecosystems and altered native plant communities. Early photographs of rangelands in east-central Oregon were gathered; their dates range from 1880 to the early 1930 's. Photo-sites were re-photographed in 1976. Photoset comparisons show expansions of western juniper (Juniperus occidentalis) populations into adjacent rangeland ecosystems.
\end{abstract}

The desire to develop ecologically sound fire management techniques has risen from the realization that fire is an inherently natural phenomenon and from the growing interest in fire as a tool in managing biotic resources. Lightningstrike frequencies, fire suppression records, climatological data, plant species and age class distributions, and other ecological indices have been used to estimate natural fire frequencies and periodicities and to guide the development of fire management policies. Attention to contemporary ecological parameters alone, however, can be quite misleading and is not an adequate basis for the formulation of simulated fire regimens, because it does not account for the role of human culture in determining "natural" fire patterns, both historically and aboriginally.

Broadcast burning by the native peoples of the inland Pacific Northwest was widespread and persisted over an extended period primevally. It may have dominated, perhaps largely pre-empted, natural burning in shaping aboriginal environments. The entry of European culture to the region interrupted native traditions in the use of fire, altered their role in nature, and distorted their prior relation to grazing phenomena, causing fundamental shifts in native ecosystems which continue to this day.

\footnotetext{
Author is with the Department of Fisheries and Wildlife, Oregon State University, Corvallis 97331 .

This research was supported by the Department of Interior, National Park Service, through the Cooperative Park Studies Unit at Oregon State University, Corvallis. Dr. Edward E. Starkey, director of the Unit, and his staff deserve a large measure of gratitude, for without their aid this work could not have begun. To William Farrell, extension agent for Grant County, Oregon, and to the many kind people the author was fortunate to meet during his travels in eastern Oregon, he extends his sincere appreciation for their interest and generosity.

Manuscript received April 2, 1979.
}

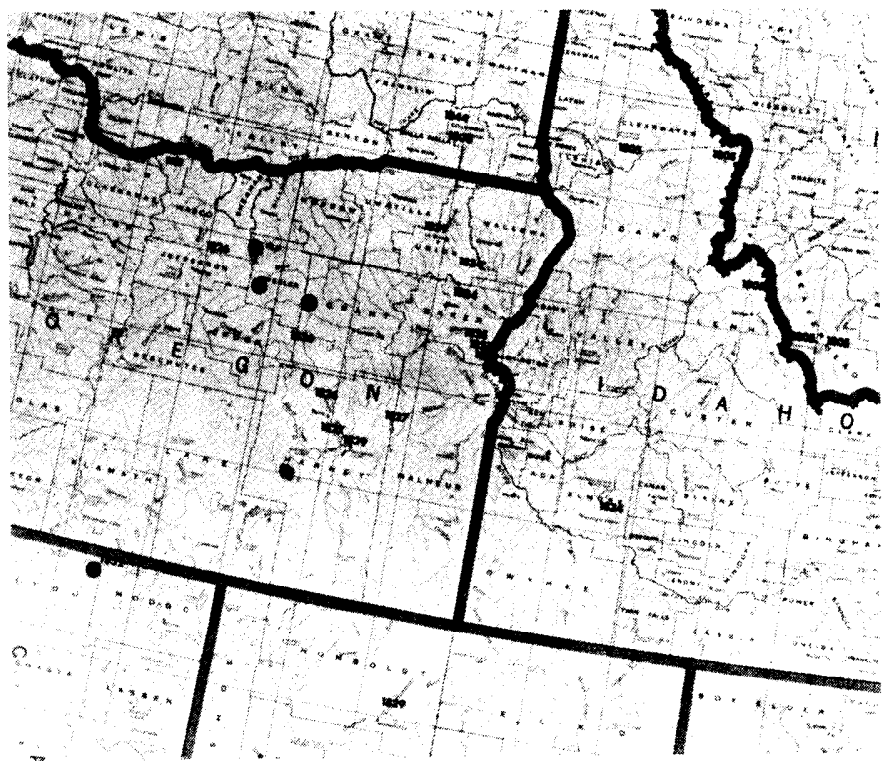

Fig. 1. Location map of fires and burned vegetation cited in historical journals.

The following discussion will examine the cultural influence on fire and its relation to grazing in the inland Pacific Northwest with special reference to: (1) the vegetation ecology of the region, particularly with respect to shrub-steppe areas; (2) the environmental relation of native grazing animals and aboriginal broadcast burning; (3) the historical events that altered the original relationship of these factors and their influence on existing "natural" ecosystems; (4) the character of changes that resulted; and (5) some of their environmental consequences.

\section{Description of the Study Area}

The discussion covers quite a broad geographic region, rather than a particular study site. The area of interest compasses most of Oregon east of the Cascade Mountains and areas of Washington, Idaho, Nevada, and California adjacent to that portion of Oregon. This region will be referred to here as the inland Pacific Northwest (Fig. 1). The time span considered in the study extends from the distant past to about the middle of this century.

The physiography of the region is characterized by steep rocky slopes, and dry breezy plains. Precipitation ranges from $127 \mathrm{~mm}$ to $508 \mathrm{~mm}$ annually $(127 \mathrm{~mm}$ to $254 \mathrm{~mm}$ annually over much of the area of particular interest here) occurring principally during winter and early spring. Such 
low levels of precipitation are critical due to their high spatial and temporal variability and to high evaporation during summer and fall (Stoddart and Smith 1943; Sweeney 1968; Griffiths 1902, 1903).

In Oregon east of the Cascade Range, shrub-steppe regions occur largely in the south and east with some extension into the north. In the north, however, native bunchgrasses originally dominated large areas, probably forming almost pure stands (Franklin and Dyrness 1973; Stoddart and Smith 1943). The vegetation of these regions is not homogeneous, however. Much diversity among individual sites results from wide variability in topography, soils, local climate, and drainage characteristics. Generally, deeprooted semidesert shrubs constitute the dominant overstory vegetation, big sagebrush (Artemisia tridentata) being the most prominent (Stoddart and Smith 1943; Tisdale, Hironaka and Fosberg 1969). Three perennial grass associates generally dominate the understory: the needlegrasses (Stipa sp.), which occur on dry sites; bluebunch wheatgrass (Agropyron spicatum), which occupies intermediate sites and is usually the most extensive, and Idaho fescue (Festuca idahoensis), which occurs on moister sites. Cheatgrass(Bromus tectorum), an exotic annual, has invaded throughout the area and may dominate locally (Franklin and Dyrness 1973; Stoddart and Smith 1943; Tisdale et al. 1969; Wright and Britton 1976).

Attention in this study centers on the steppe, shrub-steppe and desert shrub regions of the inland Pacific Northwest (as defined by Franklin and Dyrness 1973), with some emphasis on areas occupied by Artemisia/Agropyron association. To develop a complete account of relevant phenomena, however, the discussion will have a broader focus, with some reference also to forests and woodlands occurring in the region. The geographic area occupied by the Artemisia/Agropyron association, or by successional stands derived from it, has remained virtually constant overall since the beginning of European settlement, though in many areas shrub populations have expanded at the expense of herbaceous flora (Tisdale et al. 1969). Western juniper (Juniperus occidentalis) woodlands occur at intermediate elevations between shrub-steppe regions below and coniferous forests above. The juniper vegetation type is very close ecologically to the Artemisia/Agropyron type and intermixes with it in some places. In recent years, western juniper populations have encroached considerably into adjacent shrub-steppe areas (Franklin and Dyrness 1973; Stoddart and Smith 1943). Coniferous forest areas of the region are centered in the Blue Mountains to the north and east and in the Cascade Mountains to the west.

\section{Ecology of Shrub-Steppe Regions in the Study Area}

In sagebrush/bunchgrass vegetation, a strong competitive relationship exists between the shrub overstory and the herbaceous understory. Healthy grasses may eliminate sagebrush seedlings through competition, but if severe drought, grazing or other perturbation reduces the vigor of grasses, many shrub seedlings may become established. If so, shrub species may grow vigorously during subsequent years and achieve significant advancement over herbaceous species as a result of reduced competition with grasses for moisture. On the other hand, reduction or removal of the shrub overstory enhances the opportunity for the herbaceous understory to increase if an adequate seed source is available.
Generally, in a healthy co-dominant stand of the Artemisia/Agropyron association, if the growth or reproductive capacity of the herbaceous species is inhibited, shrubs prosper; but if the shrub population is damaged or destroyed, herbaceous species can expand their influence (Daubenmire 1940, 1974).

Strong competition also exists between native perennial species and alien annuals. Cheatgrass, which grows rapidly and matures early in spring, may pre-empt bluebunch wheatgrass seedlings and eliminate them. If an established bunchgrass population is injured during its periods of active growth, its competitive capacity is diminished, allowed cheatgrass populations to expand rapidly (Daubenmire 1940, 1974).

\section{Fire and Grazing}

The steppe and shrub-steppe regions of the inland Pacific Northwest reflect features characteristics of landscapes having close associations with fire. Both their dry climate and their even surface configuration favor widespread burning. Periodic drought and strong steady winds cause plains vegetation to become seasonally very dry and readily flammable. Thus, a single fire may range extensively over an area having a relatively uniform fuel supply. Many plant species native to dry plains environments have adapted to recurrent burning by developing resistant or resiliant characteristics (Agee 1974; Humphrey 1974; Sweeney 1968).

Fire is especially harmful to shrubs during drought years and may destroy individuals of both sprouting and nonsprouting species (Wright 1972; Wright and Brit:-n 1976). If the subsurface structures of sprouting shrubs are not seriously damaged, they may recover within 10 years, but nonsprouters must depend on seed reproduction and generally do not recover as rapidly (Stoddart and Smith 1943; Wright 1972). In either case, periodic burning usually destroys many years of shrub growth, and afterward several years are required for the population to regain maturity (Humphrey 1974). Frequent fires, even of low intensity, may keep shrub populations in the juvenile, nonfruiting state, because seedlings are killed more readily than larger plants, thus precluding maturation and seed production (Humphrey 1963,1974$)$. On the other hand, a moderate fire destroys only a single year's growth of perennial grasses, the roots and growth-active structures usually avoiding serious injury (Humphrey 1958, 1974). Recently burned grasses, however, are highly vulnerable to damage by close grazing (Komarek 1965). In the inland Pacific Northwest, fires in late summer and autumn, as they occur most often naturally, favor coolseason perennial grasses which are then dormant. Early spring fires are more likely to kill shrubs and to subdue native perennial bunchgrass during their primary period of growth, thus opening space for annuals, such as cheatgrass, to invade (Wright 1972; Wright and Britton 1976).

The impact of grazing on plant distributions in shrubsteppe regions depends in part on the frequency, intensity and selectivity of cropping, and on the season of occurrence (Willard and McKell 1973). Grazing becomes damaging to herbaceous populations (and thereby favorable to shrub populations through reduction of herbaceous competition) when cropping occurs during the critical period of spring growth or when too much photosynthetic tissue is removed (Stoddard and Smith 1943). Both result in a loss of vigor and density among herbaceous species, which then permits 
shrub species to advance (Cooper 1953). Bluebunch wheatgrass and Idaho fescue are decreasers and cheatgrass and big sagebrush are increasers under heavy grazing (Moomaw 1957).

Daubenmire (1974) found that lightly grazed grasses declined after full protection from grazing, and Humphrey (1953) found that the number and rate of encroachment of woody species was greater on protected than on grazed sites. Thus, suitable grazing may stimulate herbaceous production; neither the absence of grazing nor optimum grazing behaviors alone are sufficient to prevent encroachment by shrubs (Cotton 1904; Harniss and Murray 1973; Humphrey 1958).

In the inland Pacific Northwest, fire and grazing are linked in the competitive relationship between woody and herbaceous species. In general these agencies act reciprocally in the flux of sagebrush and bunchgrass populations in the Artemisia/Agropyron association-fire tends to favor the perennial grasses over shrubs and excessive grazing tends to deplete herbaceous populations allowing woody species to increase (Harniss and Murray 1973; Tisdale et al. 1969).

But the interactions between fire and grazing are much more complex than this. If a healthy stand of perennial grasses is burned, resilient species profit, though perhaps only temporarily, from increased nitrification effects ànd from release of mineral nutrients to the soil (Humphrey 1958; Stoddart and Smith 1943). Therefore, the fresh shoots which emerge afterward generally have higher protein and mineral contents than grasses of unburned areas, thus stimulating vigorous herbaceous regeneration (Christensen and Muller 1975; Komarek 1965, 1967). But because this new growth is more palatable and more nutritious, burned sites tend to be particularly attractive to herbivores, and grazing activity may then become concentrated on burned areas. Grass populations may suffer severe depletion if new shoots are too closely and too promptly cropped (Komarek 1965). This may offset the negative impact of fire on shrubs and allow them to recover more rapidly and to expand beyond their previous population levels. Drought may complicate these effects by aggravating the stress on herbaceous species and inhibiting their productivity, thus further reducing competition from grasses. The impact of burning on shrubs may also diminish if grass populations become too sparse to carry fire (Wright 1972). If shrubs and grasses are both seriously damaged by fire and grazing, exotic, aggressive annuals may invade and dominate large areas (Tisdale et al. 1969; Wright and Britton 1976). On the other hand, moderate and timely grazing of healthy vegetation can stimulate herbaceous production and permit grasses to subordinate shrubs (Cooper 1953; Cottam and Steward 1940; Ellison 1960).

During the distant past, natural grazing behaviors of native animals contributed to the variability of fires on open rangelands, probably leading to a patchy mosaic pattern of burned areas (Ellison 1960; Komarek 1965). Though an assessment of grazing activities of fauna present in the study area prior to the influx of European influences can only be made indirectly, it appears that no vast herds of grazing ungulates, comparable to the bison populations of the Great Plains, have existed here for several thousand years. The nature of the native flora, which are not well adapted to cropping and trampling, supports this belief (Daubenmire
1970; Heady 1968). Considering our knowledge of fire and grazing, as outlined here, their relationships may have been particularly influential primevally in affecting the relative distributions of herbaceous and woody species in the shrubsteppe regions of the inland Pacific Northwest.

The presence, and even the absence, of large herbivores has contributed formatively to the nature of range vegetations all over the world (Graham 1956). Whereas the Great Plains of North America are known to have supported vast herds of bison prior to the intervention of European hunters, the character of native grazing activities in the inland Pacific Northwest, and its role in the development of the native flora there, are less apparent. The influence of large grazing animals probably declined after the Pleistocene Epoch, as many Ice Age mammals were eliminated by postglacial climatic changes, and also perhaps by the influx of primitive hunting cultures west of the Rocky Mountains (Daubenmire 1970; Martin and Wright 1967; Sauer 1944, 1950). The occurrence of bison west of the Rocky Mountains, after the extinction of ancient forms, appears to have been comparatively recent and sporadic (Galbraith and Anderson 1971); available evidence indicates that bison were virtually absent from the Intermountain West, or constituted at most a modest and transient influence there, for an extended period prior to the force of European expansion (Hains 1967; Lewis and Clark 1959; Ogden, 1961; Roe 1970). It is generally agreed that bison were certainly not present west of the Rocky Mountains in numbers comparable to those present on the Great Plains prior to European intervention.

\section{Broadcast Burning in the Primeval Environment}

Cultural broadcast burning apparently began in the Pacific Northwest thousands of years ago as part of the economies of Pleistocene hunters, who entered the New World from Asia in pursuit of large Ice Age mammals. During the middle Pleistocene, North America was populated by the most diverse assemblage of large fauna ever to occupy the continent (Sauer 1944; Strong 1969). Though only minor evolutionary changes affected these species prior to man's entry, afterwards many forms suffered relatively rapid extinction (Sauer 1944, 1950). This was probably due, in part, to climatic change at the close of the Pleistocene. Change was slow, however, not catastrophic, allowing ample opportunity for migration. Archaelogical remains of early North American hunters demonstrate close association with these ancient fauna, and some measure of responsibility for their extinctions may be attributable to the advent of man's hunting culture and its use of fire (Hansen 1947; Martin and Wright 1967; Sauer 1944, 1950).

Native traditions of broadcast burning persisted into historic times and assumed a variety of purposes. A study of the journals of early European explorers and settlers in the Pacific Northwest has revealed thirty references to fires and burned vegetation in the inland Pacific Northwest (Bolten 1950; Farnham 1905; Fremont 1849; Irving 1955; Lewis and Clark 1959; Minto 1900; Ogden 1961, 1971; Palmer 1847; Stansbury 1852; Townsend 1839; Turner 1873). Locations of these observations are given in Figure 1. Twenty-four of these references attribute the cause of burning specifically to native peoples. A few are cited below:

On September 22, 1776, Escalante and his party, while traveling westward just east of Utah Lake, Utah, 
saw in front of (them) and not very far away many large columns of smoke . . . The guide Silvestre said they must have been made by his people who were out hunting. We replied to them with other smoke signals so that if they had already seen us they would not take us to be enemies and thus flee or welcome us with arrows. They replied with larger smoke signals in the pass through which we must travel to the Lake and this caused us to believe they had already seen us, because this is the most prompt and common signal used in any extraordinary occurrence by all the people of this part of America (Bolten 1950).

Hall (1967) states that according to Hodgson (1913) the Blue Mountains received that name because fires frequently shrouded the area with thick smoke prior to the turn of the century. Native peoples used the forests during the summer and occasionally set fires purposefully or allowed campfires to escape and burn over large areas.

Burnt River, which flows east from the Blue Mountains to the Snake River, was probably given that name by Ogden in 1825. Traveling in the Burnt River area again on September 21, 1827, Ogden (1961) noted that burned-over land was interfering with his progress.

In August of 1834, Bonneville's party was troubled by smoke and fire along their entire route from the mouth of Burnt River across the Blue Mountains to the Walla Walla River. After reaching the headwaters of the Powder River and crossing to the Grande Ronde River, they saw that all the plains and meadows of the Grande Ronde Valley were burning. Washington Irving, a chronicler of Bonneville's adventures in the West, in relating this event, wrote that this "was the season of setting fires to the prairies,"implying that the conflagration Bonneville witnessed resulted from the customary burning practiced by the native inhabitants (Irving 1955).

While traversing the Blue Mountains in the vicinity of the Grande Ronde Valley on August 31, 1834, Townsend saw that "the grass has been lately consumed, and many of the trees blasted by the ravaging fires of the Indians." Two years later, on the evening of September 3, 1836, while watching another fire in progress, Townsen noted that

the Indians have fired the prairie, and the whole country for miles around is most brilliantly illuminated. The very heavens themselves appear ignited ... (Townsend 1839).

In 1900, John Minto set forth one explanation for broadcast burning by the native peoples of this region: "The tribes on the south bank of the Snake River, and southward, used to fire the high, arid plains, where possible, and collect the crickets and grasshoppers thus killed" (Minto 1900).

Fire was also used by native tribes in present east-central Oregon. Ogden traversed this region repeatedly as an agent of the Hudson's Bay Company and was occasionally troubled by fire and burned vegetation, which he attributed to the local inhabitants. While moving southward east of the Deschutes River between September 24 and 26, 1826, Ogden reported that the land had been recently burned over. On October 4, 1826, then in the upper Crooked River area near present Paulina, Oregon, Ogden wrote that his party

had certainly a most providential escape last night. The Indians crossed the river (probably at Beaver Creek near the mouth of Wolf Creek) in the night and set fire to the plain within ten yards of our camp ... it blowing a gale at the time.

Eight months later on June 22, 1827, after ten days of illness and immobility in the hills northwest of Malheur Lake, Ogden wrote:

Many small Streams have been discovered in the Mountains and were not long since well supplyed with Beaver but unfortunately the Natives have destroyed them all and probably by the aid of fire which is certainly a most distructive mode of extirpating them for scarcely ever one escapes particularly when the Streams are not wide, and from what
I have seen in this my last years travel I will venture to assert withou exageration the Natives have destroyed and principally by fire upward of sixty thousand Beavers ... (Ogden 1961).

Ogden made three other references to fires, imputing thei1 cause to native peoples: On July 15,1827 , while at the Malheur River south of present Drewsey, Oregon; on June 7, 1829, while moving toward present Oregon north o: present Winnemuca, Nevada; and on June 20, 1829, then or the northern shore of Malheur Lake at the mouth of the Silvies River. On this last occasion he wrote:

From the number of fires seen by us in all directions this day the native: are already aware of our arrival.

It is interesting to note that though Ogden states that these fires were preceded by heat and lightning, he confidently assigned their cause to the local inhabitants (Ogden 1961 1971).

Fremont (1849) and Stansbury (1852) also referred tc fires used in signalling. Fremont (1849) wrote:

Columns of smoke rose over the country at scattered intervals - signals by which the Indians, as elsewhere, communicate to each other that enemies are in the country. It is a signal of ancient and very universa application among barbarians.

Stansbury (1852) reported that his party

observed from the high ground, the smokes of numerous Indian Signa fires, rising in several directions-an intimation that strangers have been discovered in the country.

\section{Native Cultural Uses of Broadcast Burning}

Prior to the intervention of European culture in the inland Pacific Northwest, the native Desert Archaic Culture, which was founded on the hunting/gathering way of life, remained virtually unchanged after its inception in the region thousands of years ago (Driver 1969; Jennings 1968; Strong 1969). Broadcast burning, for an array of purposes, was apparently a traditional practice during this extended period. But because the physiography of the region is so varied, it is unlikely that fire was used everywhere with equal regularity. It is likely that fire was applied periodically to particular areas where desired objectives could be achieved, such as: (1) in bottomlands and meadows where the production and quality of wild forage could be enhanced and the production and accessibility of plant foods could be improved; (2) in forests where hunting and travel could be facilitated by burning away underbrush and berry production could be enhanced [The Klamath of southern Oregon and the Pomo of California complained that the whites' policy of excluding fire from their forest habitats was depriving them of their traditional hunting grounds because the brush, which they formerly had burned periodically, had become so overgrown that game was scarce and effective pursuit of prey was impossible (Stewart 1956).]; (3) on grass/shrub plains where game could be encircled or driven [A Coeur d'Alene tale was found in which the use of a fire corral is described (Reichard 1947).], distant signals could be made and detected, advantage could be gained in battle, and shrubs could be subdued and grasses stimulated to attract game.

The regularity with which the grass/shrub plains were burned primevally cannot be determined with certainty, but three factors merit consideration: (1) these plains are extensive; (2) they contain meager resources; and (3) aboriginally they supported relatively sparse populations of both man and his prey. These considerations would seem to argue against frequent cultural burning of any particular areas, especially those remote from sites of regular human habita- 
tion. Indeed, some areas, or some types of vegetation, may not have been purposefully burned with any regularity. This is not to suggest that fire was not periodically and broadly applied to grass/shrub plains but that purposeful burning over these extensive areas may not have been as conscientiously regulated nor as evenly distributed through time as it may have been where richer resources could be manipulated to greater advantage through the regular use of fire. The influence of broadcast burning by the Paiute, who were nomadic people of the eastern Oregon plains, however, may have been widespread, extending even into remote areas.

Though these plains areas contain only meager resources, three of importance could be manipulated, enhanced and effectively exploited through the use of fire. These were: (1) prey, whether it be large game or edible insects; (2) the habitat these prey require, and (3) wild grains. Of the references to burning found in historic journals for which specific dates could be determined, $71 \%$ were dated in late summer and autumn. Of these $65 \%$ explicitly attributed the cause of burning to native inhabitants, actual observations of artificial fires occurring from mid-July to early October. For aboriginal desert economies, this was the season for gathering, preparing, and storing provisions for the winter. Large game could be effectively hunted by burning the vegetation around them, and because their populations were relatively sparse, some degree of predictability in locating them could be gained by managing their habitat with fire. A good supply of small game, such as crickets and lizards, could be acquired by the same means, and the grain crops derived from wild grasses in subsequent years could be enhanced. The smoke from such fires would serve to signal the gathering of tribal bands for annual convocations or migrations as well. Some portions, perhaps large portions, of less remote plains areas may have been burned with relatively high frequency, even annually, though it is not likely that any one area was burned during consecutive years. Much certainly depends on the standards and techniques current among the various native cultures.

\section{European Intervention}

Though settlement in the inland Pacific Northwest closely followed the characteristic pattern of white cultural expansion elsewhere in the West, it occurred relatively late, for settlement came first to the western reaches of the Old Oregon Territory and then returned eastward across the Cascade Range. Significant interventions in the inland region occurred later, the southeast portion of Oregon being the most recently settled (Oliphant 1948, 1968). Therefore, we are still relatively close to the early history of the region and to the events which caused environmental change there.

Native American peoples of the inland Pacific Northwest apparently burned forest and plains vegetation over an extended period primevally; ecosystems long influenced by this tradition would have assumed an environmental balance maintained by the continuation of customary broadcast burning. With the entry of European culture to the region, the environmental influence of native traditonal broadcast burning was disrupted. The use of fire was adopted by some early white stockmen and settlers and applied to their own economies-to protect their homes and property from wildfires, to clear land, to stimulate new herbaceous growth in spring, and to remove dead plant material to give livestock unobstructed access to fresh forage. But their use of fire was not tempered by tradition and long experience in local environments. There was also much carelessness with fire and much burning became promiscuous and abusive. Existing forest and range ecosystems were altered; natural resources were damaged and depleted (by burning and by overgrazing); and the use of fire, in particular, became associated in the minds of many whites with declining resource capacities (Agee 1974; Griffiths 1902, 1093; Rakestraw 1958).

As European settlement in the region advanced, strong negative attitudes toward uncontrolled fires developed. Those "who set fires that swept over the ranges" were characterized as "careless white men and malicious Indians (Oliphant 1968). In late summer of 1867 , fires caused some anxiety. Reports referred to "prowling bands of Indians" setting fires which "entirely destroyed the stock ranges" in some areas (Oliphant 1968). In 1878, more distress was voiced over prairie fires consuming grasses needed for winter livestock forage. Between 1882 and 1884 , "destructive" fires occurred on the east end of the Nez Perce Reservation in northern Idaho, in the Big Bend country of eastern Washington, and on the plains between Boise and the Snake River (Oliphant 1968). Some people (it is not clear whether they were native people or whites) contended that occasional burning of the rangelands tended to eliminate sagebrush, an observation now supported by modern research (Harniss and Murray 1973; Wright 1972; Wright and Britton 1976), but a newspaper article asserted that fires:

destroyed the bunchgrass that grows among the brush, and so heat the ground that the grass will not grow again in time for winter pasture. It is safer and better to leave the sage brush until the land is needed for cultivation, when it can be easily removed (Oliphant 1968).

But burning continued, and in November 1889, fires "ruined" rangelands in the Warner Valley of south-central Oregon, which presumably could have supported 3,000 head of cattle through the winter (Oliphant 1968).

It is unclear to what degree fire may have actually contributed to the extraordinary stock losses suffered during the winter of 1889 , nor to the losses of previous years, for these misfortunes were primarily attributed at the time to extreme cold, frozen watering places, inaccessibility of forage due to ice-crusted snow, and the failure of stockmen to provide feed.

In 1901, Griffiths (1902) saw six separate areas recently burned between Burns and Drewsey in east-central Oregon; three of these were burning as he passed. He also found evidence of fires in every mountain range he visited. Like others, Griffiths at that time bitterly lamented the burning of winter forage and attributed the cause of range fires simply to criminal negligence (Griffiths 1902). However, 9 years later he regarded the curtailment of range fires in the Southwest to be the most significant factor in the spread of shrub populations into grasslands (Griffiths 1910).

The situation on summer ranges was similar to that on wintering grounds, though on the former it was the stockmen, principally the sheepmen, who "lightburned"in the fall to "green up" forage for the next season by stimulating fresh spring growth and to clear away fallen timber that interfered with the movements of their sheep. In the spring, however, large flocks, moving up close behind the receding snow line quickly consumed fresh green shoots on burned areas before they could get a fair start. This depleted forage species and exposed soil and roots to serious damage from trampling and erosion (Agee 1974; Griffiths 1902, 1903; Rakestraw 1958). 


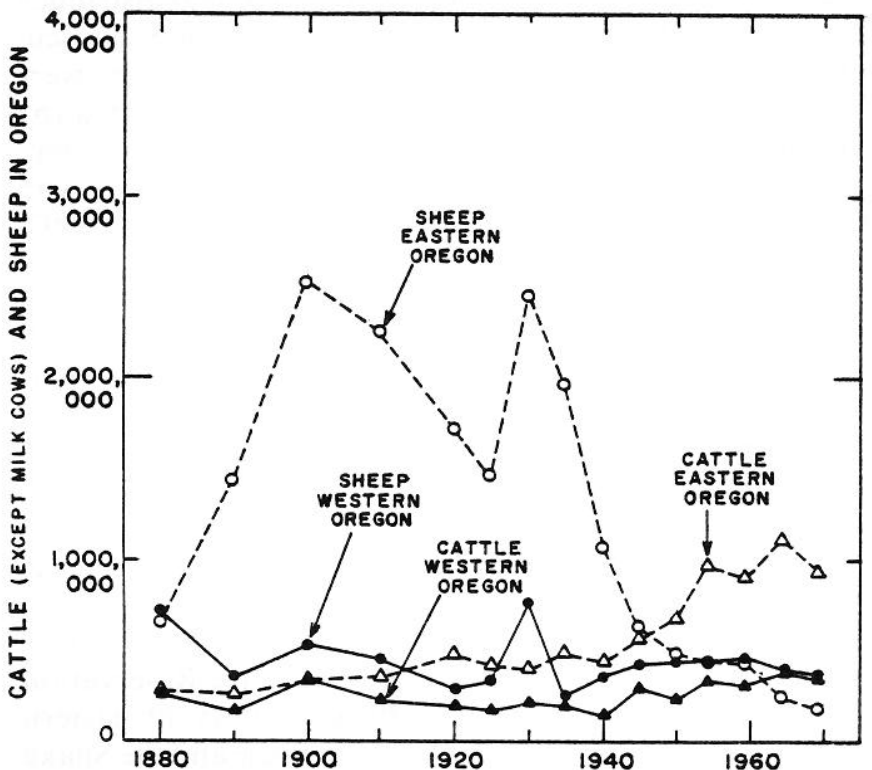

Fig. 2. Numbers of cattle (except milk cows) and of sheep in Oregon east and west of the Cascade Range from 1880 to 1969.

Initial introductions and breeding of European livestock in the inland Pacific Northwest led to the displacement of native animals by large herds of domestic stock and markedly altered foraging behaviors and intensities. Vast herds of domestic stock, sharp fluctuations in their numbers and their increasing concentration on inferior range by appropriation of better lands for farming, exerted extraordinarily severe pressure on native herbaceous species (Fig. 2) (U.S. Census 1860-1969; U.S. Census of Agriculture 19251969). The combined disturbance of natural grazing phenomena and of traditional broadcast burning regimens seriously distorted primeval relationships between fire and grazing. Extraordinary and untimely foraging pressure on native flora, "light-burning," and other promiscuous burning practices formed an especially detrimental combination. It led to the depletion of herbaceous populations and a reduction in their competitive capacity, eventually allowing shrubs to prosper as the influence of fire declined. As natural resources continued to deteriorate, anxieties grew over the need to develop some means of controlling abuses. With the growing desire to protect range, forest, and other natural resources from waste, an oversimplified view of fire developed. Many considered fire, whether used traditionally by native peoples or used by whites, to be wholly incompatible with European settlement economies. A broad policy of total fire exclusion evolved and was implicitly incorporated in federal land management standards with the establishment of forest reserves after 1891. Eventually, increasing competence in fire prevention and suppression virtually eliminated fire as an agent in the environment and promoted rather than mitigated the process of resource depletion and environmental change (Shinn 1978).

\section{Juniper Invasions}

Western juniper populations are indigenous to the inland Pacific Northwest, are closely associated with shrub/steppe vegetation without being part of it, and are responsive to changes in existing fire and grazing regimes. Therefore, this species is especially useful in demonstrating the long-term
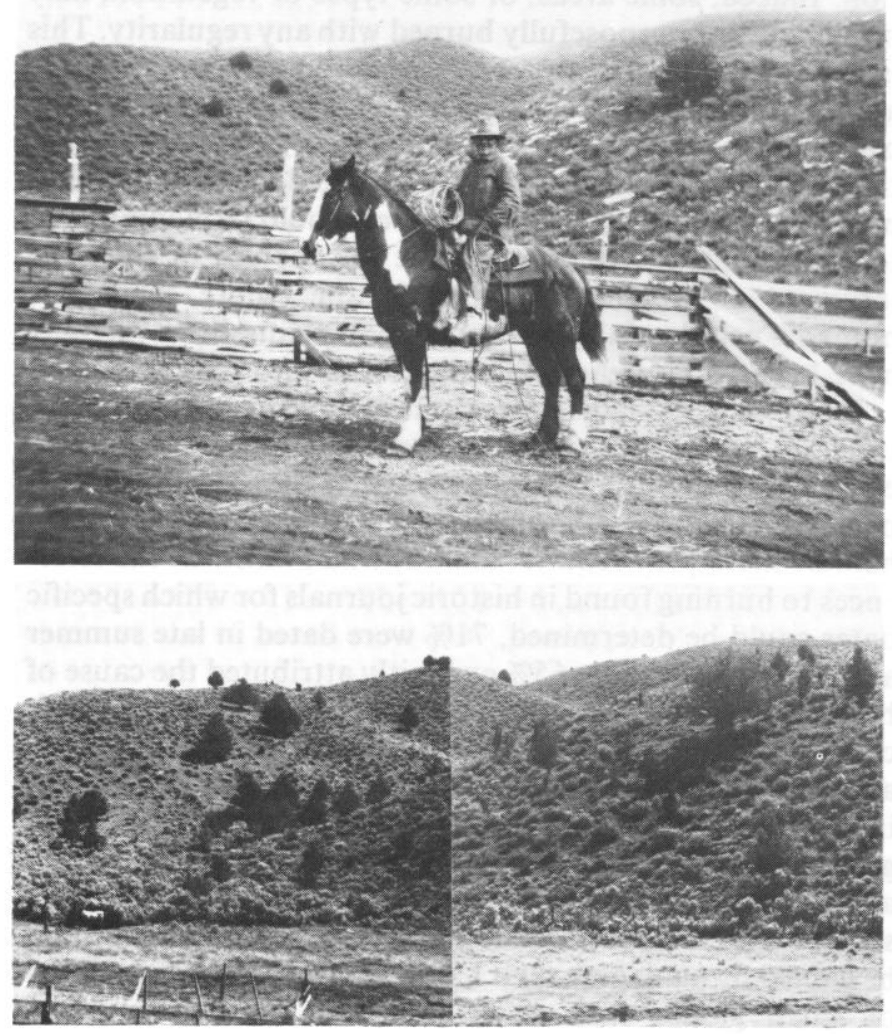

Fig. 3. A. Early 1930's; B. 1976.

environmental consequences of the historical events discussed above.

A number of early photographs were gathered in which the range vegetation of Grant County, in east-central Oregon, was pictured. The dates of these photographs range from 1880 to the mid-1930's. Each photo-site was relocated and rephotographed during the summer of 1976. Figures 3 through 5 are examples of the photo-set comparisons that
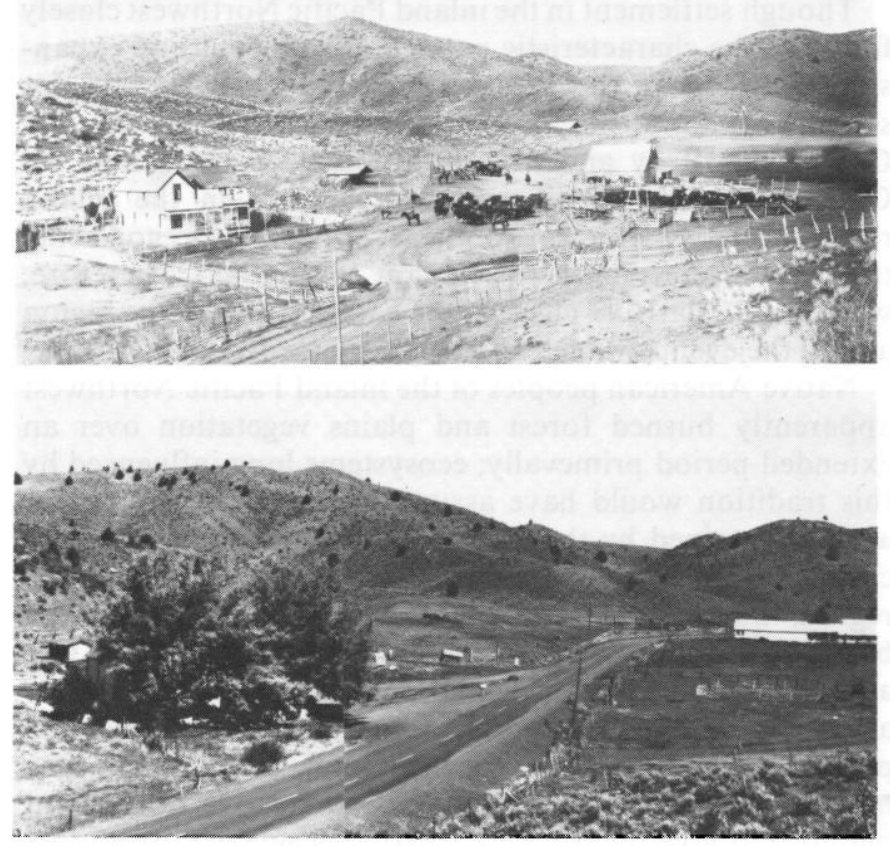

Fig. 4. A. 1900; B. 1976. 

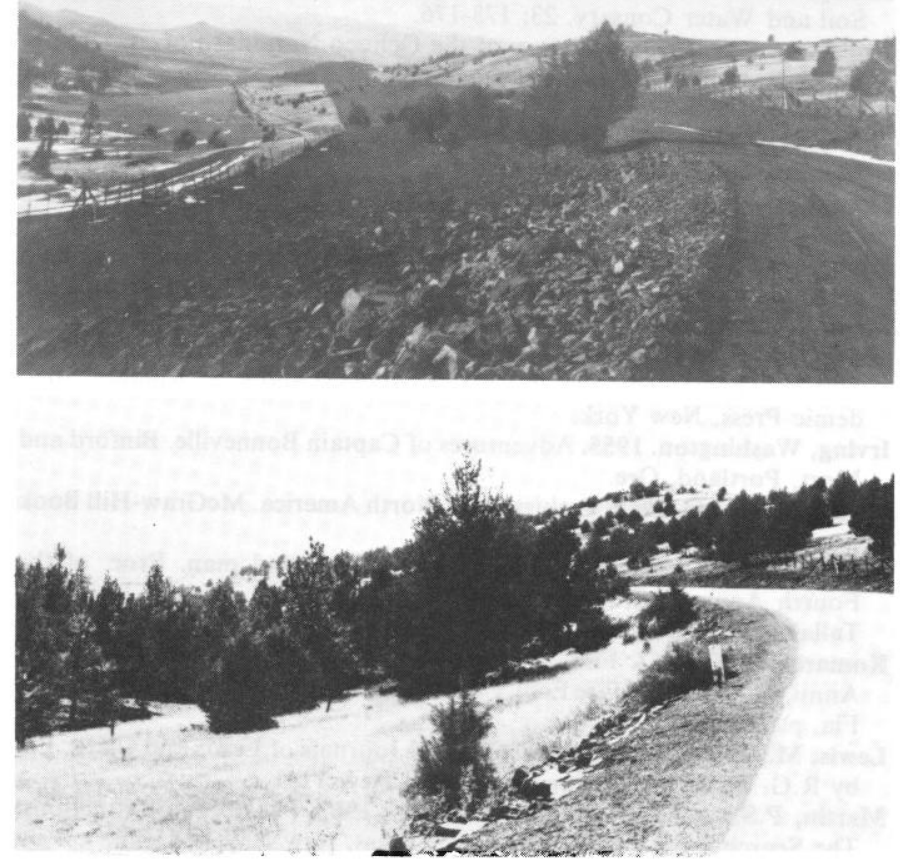

Fig. 5. A. An overgrazed livestock driveway on the left reduced to bare soil by the early 1930's. Range vegetation on the right. B. Heavy juniper invasion of the driveway on the left and of the rangeland on the right. Ponderosa pine (Pinus ponderosa) has advanced at extreme left.

resulted. Western juniper populations have increased at all photo-sites. Very low population densities and the immaturity of individuals present on sites photographed earliest indicates that juniper invasions were then recent. On one site photographed in 1920,1945, 1956, and 1965, juniper expansion has been particularly notable (Fig. 6).

Burkhardt and Tisdale (1976) found that in southwestern Idaho, fires were frequent for at least several hundred years prior to European settlement. They attribute the decreased frequency of fires during the last century to fire control activities, to construction of roads and other fire barriers, and to reduced fuel loadings due to heavy grazing and a decline in precipitation. Their research also indicates that juniper invasions are directly related to the cessation of periodic burning.

\section{Summary and Conclusions}

In summarizing the ecological history of fire in the inland Pacific Northwest, the following sequence of events can be outlined:

1) Cultural broadcast burning apparently began in the region with the entry of early hunting cultures during the Pleistocene Epoch and may have contributed to the extinction of many large Ice Age mammals.

2) Native cultural traditions of broadcast burning apparently persisted within the region from the distant past into historical times and had a variety of purposes when first observed by Europeans.

3) White stockmen and settlers initially adopted the use of fire and applied it to their own economies, but their conduct with it was not consistent with long-standing native cultural standards and much burning became abusive to native ecosystems.

4) The displacement of native animals by large herds of
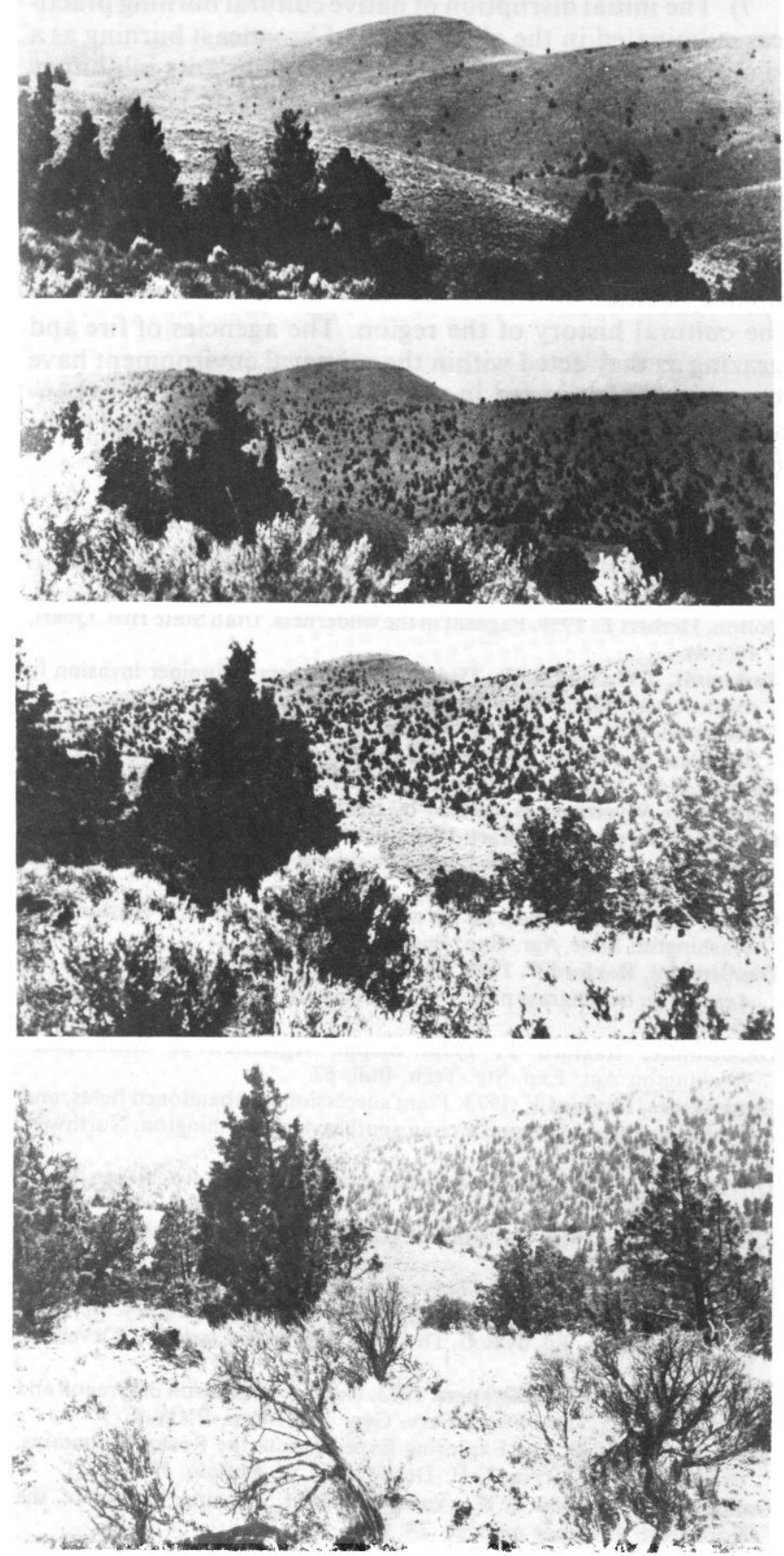

Fig. 6 A. 1920; B. 1945; C. 1956; and D. 1965.

domestic stock significantly altered primeval grazing behaviors and intensities. Extraordinary and untimely grazing pressure on herbaceous species, combined with promiscuous burning practices, disrupted natural ecosystems and depleted native forage.

5) Uncontrolled fires, in particular, became associated with the deterioration of forest and range resources and a negative and oversimplified view of fire in the natural environment evolved.

6) A broad policy of fire exclusion developed, and eventually, an increasing competence in fire prevention and sup- 
pression virtually removed fire from natural ecosystems.

7) The initial disruption of native cultural burning practices culminated in the elimination of broadcast burning as a significant environmental agent, thus ending its inhibitory influence on shrubs and its positive effect on herbs.

8) Western juniper populations in east-central Oregon have expanded markedly during the last 75 years in response to the distortion of primeval relationships between fire and grazing which has occurred during the same period.

Thus, the native character of natural ecosystems in the inland Pacific Northwest has been significantly affected by the cultural history of the region. The agencies of fire and grazing as they acted within the primeval environment have been virtually inverted in some areas, leading to an expansion of shrub populations at the expense of grasses and forbs (Shinn 1978).

\section{Literature Cited}

Agee, James K. 1974. Fire management in the National Parks. West. Wild. 1: 27-33.

Bolton, Herbert E. 1950. Pageant in the wilderness. Utah State Hist. Quart. 18(1-4).

Burkhardt, J.W., and E.W. Tisdale. 1976. Causes of juniper invasion in southwestern Idaho. Ecology 57: 472-484.

Christensen, N.L., and C.H. Muller. 1975. Effects of fire on factors controlling plant growth in Adenostoma chaparral. Ecol. Monog. 45: 29-55.

Copper, H.W. 1953. Amounts of big sagebrush in plant communities near Tensleep, Wyoming, as affected by treatment. Ecology 34: 186-189.

Cottam, W.P., and G. Stewart. 1940. Plant succession as a result of grazing and of meadow desiccation by erosion since settlement in 1862 . J. Forest. 38: 613-626.

Cotton, J.S. 1904. A report on the range condition of central Washington. Washington State Agr. Exp. Sta. Bull. 60.

Daubenmire, Rexford F. 1940. Plant succession due to overgrazing in the Agropyron bunchgrass prairie of southeastern Washington. Ecology 21: 55-64.

Daubenmire, Rexford F. 1970. Steppe vegetation of Washington. Washington Agr. Exp. Sta. Tech. Bull. 62.

Daubenmire, Rexford F. 1974. Plant succession on abandoned fields, and fire influences, in a steppe area in southeastern Washington. Northwest Sci. 48

Driver, H.E. 1969. Indians of North America. Univ. of Chicago Press, Chicago, Ill.

Ellison, Lincoln. 1960. Influence of grazing on plant succession of rangelands. Bot. Rev. 26: 1-78.

Farnham, Thomas J. 1905. Travels in the Great Western Prairies, the Anahuac and Rocky Mountains, and in the Oregon Country. In: Early Western Travels. Ed. by R.G. Thwaites. Arthur H. Clark Co., Cleveland, O.

Franklin, J.F., and C.T. Dryness. 1973. Natural Vegetation of Oregon and Washington. USDA Forest Serv. Gen. Tech. Rep. PNW-8.

Fremont, J.C. 1849. The Exploring Expedition to the Rocky Mountains, Oregon and California. G.H. Derby and Co., Buffalo, N.Y.

Galbraith, W.A., and E.W. Anderson. 1971. Grazing history of the Northwest. J. Range manage. 24: 6-12.

Graham, Edward H. 1956. The recreative power of plant communities. In: Internat. Symp. on Man's Role in Changing the Face of the Earth. Ed. by W.L. Thomas. Univ. of Chicago Press, Chicago, Ill. p. 677-691.

Griffiths, David. 1902. Forage conditions of the northern border of the Great Basin. USDA Buruea of Plant Industry. Bull. No. 15.

Griffiths, David. 1903. Forage conditions and problems in eastern Washington, eastern Oregon, northeastern California and northwestern Nevada. USDA Bureau of Plant Industry Bull. No. 38.

Griffiths, David. 1910. A protected stock range in Arizona. USDA Bureau of Plant Industry Bull. No. 177.

Haines, Francis. 1967. Western limits of the buffalo range. Amer. West. 4: 4-12, 66-67.

Hall, Frederick C. 1967. Vegetation-soil relations as a basis for resource management in the Ochoco National Forest of central Oregon. Ph.D. Diss. Oregon State Univ., Corvallis.

Harniss, R.C. and R.B. Murray. 1973. Thirty years of vegetal change following burning of sagebrush-grass range. J. Range Manage. 26: 322325.
Heady, Harold F. 1968, Grassland response to changing animal species. J. Soil and Water Conserv. 23: 173-176.

Hodgson, A.H. 1913. A history of the Ochoco National Forest. Unpublished material filed in the Ochoco National Forest Office. Prineville, Ore.

Humphrey, R.R. 1953. The desert grassland, past and present. J. Range Manage. 6: 159-164.

Humphrey, R.R. 1958. The desert grassland: a history of vegetational change and an analysis of causes. Bot. Review 24(4): 193-252.

Humphrey, R.R. 1963. The role of fire in the desert and desert grassland areas of Arizona. Proc. of the Second Annual Tall Timbers Fire Ecol. Conf. Tall Timbers Research Sta., Tallahassee, Florida. p. 45-61.

Humphrey, R.R. 1974. Deserts and desert grasslands of North America. In: Fire and Ecosystems. Ed. by T.T. Kozlowski and C.E. Ahlgren. Academic Press, New York.

Irving, Washington. 1955. Adventures of Captain Bonneville. Binford and Mort, Portland, Ore.

Jennings, Jesse D. 1968. Prehistory of North America. McGraw-Hill Book Co., New York.

Komarek, E.V. 1965. Fire ecology-grasslands and man. Proc. of the Fourth Annu. Tall Timbers Fire Ecol. Conf. Tall Timbers Res. Sta., Tallahassee, Fla. p. 169-220.

Komarek, E.V. 1967. Fire-and the ecology of man. Proc. of the Sixth Annu. Tall Timbers Fire Ecol. Conf. Tall Timbers Res. Sta., Tallahassee, Fla. p. 143-170.

Lewis, M., and W. Clark. 1959. Original Journals of Lewis and Clark. Ed. by R.G. Thwaites. Antiquarian Press, New York.

Martin, P.S., and H.E. Wright, Jr. (Eds.) 1967. Pleistocene Extinctions: The Search for a Cause. Yale Univ. Press, New Haven, Conn.

Minto, John. 1900. The number and condition of the native race in Oregon when first seen by white men. Oregon Hist. Quart. 1(13): 296-315.

Moomaw, James C. 1957. Some effects of grazing and fire on vegetation in the Columbia Basin Region, Washington. Doctoral thesis. State College of Washington, Pullman.

Ogden, Peter S. 1961. Ogden's Snake Country Journal: 1826-1827. Ed. by K.G. Davies. Hudson's Bay Record Soc., London.

Ogden, Peter S. 1971. Ogden's Snake Country Journal: 1827-1829. Ed. by G. Williams. Hudson's Bay Record Soc., London.

Oliphant, J. Orin. 1948. History of livestock industry in the Pacific Northwest. Oregon. Hist. Quart. 49: 3-29.

Oliphant, J. Orin. 1968. On the Cattle Range of the Oregon Country. Univ. of Washington Press, Seattle.

Palmer, Joel. 1847. Journal of travels over the Rocky Mountains to the mouth of the Columbia River; made during the years 1845 and 1846. In: Early Western Travels. Ed. by R.G. Thwaites. Arthur H. Clark. Co., Cleveland, $\mathbf{O}$.

Rakestraw, Lawrence. 1958. Sheep grazing in the Cascade Range: John Minto vs. John Muir. Pacific Hist. Rev. 27: 371-382.

Reichard, Gladys A. 1947. An analysis of Coeur d'Alene Indian Myths. Mem. Amer. Folklore Soc. Vol. 41.

Roe, Frank G. 1970. The North American Buffalo: a Critical Study of the Species in Its Wild State. Univ. of Toronto Press, Toronto.

Sauer, C.0. 1944. A geographical sketch of early man in America. Geog. Review 34: 529-573.

Sauer, C.O. 1950. Grassland climax, fire, and man. J. Range Manage. 3: 16-21.

Shinn, D.A. 1978. Man and the land: an ecological history of fire and grazing on eastern Oregon rangeland. Master's thesis. Oregon State Univ., Corvallis.

Stansbury, H. 1852. An Expedition to the Valley of the Great Salt Lake of Utah. Sampson Low, Son and Co., London.

Stewart, Omer C. 1956. Fire as the first great force employed by man. In: Internat. Symp. on Man's Role in Changing the Face of the Earth. Ed. by W.L. Thomas. Univ. of Chicago Press, Chicago, Ill.

Stoddart, L.A., and A.D. Smith. 1943. Range Management. McGraw-Hill Book Co., New York.

Strong, Emory. 1969. Stone Age in the Great Basin. Binford and Mort, Portland, Ore.

Sweeney, James R. 1968. Ecology of some "fire type" vegetation in northern California. Proc. of the Seventh Annual Tall Timbers Fire Ecol. Conf. Tall Timbers Research Sta., Tallahassee, Florida. p. 111-125.

Tisdale, E.W., M. Hironaka, and M.A. Fosberg. 1969. The sagebrush region of Idaho. Univ. of Idaho Agri. Exp. Sta. Bull. 512.

Townsend, John K. 1839. Narrative of Journey Across the Rocky Mountains to the Columbia River and a Visit to the Sandwich Islands, Chili, and with a Scientific Appendix. In: Early Western Travels. Ed. by R.G. Thwaites. Arthur H. Clark, Co., Cleveland. 
Turner, W.M. 1873. Scraps of Modoc History. Overland 11(21): 21-25. United States Census. 1860-1969.

United States Census of Agriculture. 1925-1969.

Willard, E.E., and C.M. McKell. 1973. Total herbage production and harvest yield as related to simulated grazing systems. Utah State Univ. Agr. Exp. Sta. Res. Rep. 10.
Wright, Henry A. 1972. Shrub response to fire. USDA Gen. Tech. Rep. INT-1, Intermountain Forest and Range Exp. Sta., Ogden, Utah. Wright, Henry A. 1974. Range burning. J. Range Manage. 27: 5-11. Wright, Henry A. and C.M. Britton. 1976. Effects of fire on vegetation in western rangeland communities. Taken from "The Role of Prescribed Burning in Western Range and Woodland Ecosystems-Symp. Proc. No. 3, Utah State Agr. Exp. Sta., Logan, Utah. (Unpublished) 